\title{
NAKŁADY NA EDUKACJE NA TLE UZYSKIWANYCH EFEKTÓW KSZTAŁCENIA
}

\author{
Paulina Ucieklak-Jeż', Agnieszka Bem² \\ ${ }^{1}$ Akademia im. Jana Długosza w Częstochowie, Wydział Filologiczno-Historyczny \\ ${ }^{2}$ Uniwersytet Ekonomiczny we Wrocławiu, Wydział Zarządzania, Informatyki i Finansów
}

\begin{abstract}
Streszczenie: W większości krajów oświata jest finansowana w modelu mieszanym - ze środków publicznych i prywatnych, przy czym udział środków prywatnych zwiększa się wraz z przechodzeniem na wyższe szczeble edukacji. Celem pracy jest analiza poziomu nierówności edukacyjnej, w oparciu o dane liczbowe opisujące wydatki na cele oświatowe w wybranych krajach oraz poziom umiejętności uczniów, którzy ukończyli 15. rok życia. W analizie wykorzystano wyniki międzynarodowego badania koordynowanego przez Organizację Współpracy Gospodarczej i Rozwoju (OECD) - Programme for International Student Assessment (PISA).
\end{abstract}

Słowa kluczowe: oświata, finansowanie, nierówności, PISA

DOI: 10.17512 /znpcz.2017.4.2.11

\section{Wprowadzenie}

Nierówności edukacyjne można analizować na poziomie dwóch bardzo szerokich wymiarów:

- nierówności warunków życia uczniów, pochodzenia;

- nierówności w zakresie osiąganych wyników nauczania, ocenianych na podstawie testów kompetencji.

W niniejszej pracy nierówności edukacyjne będą analizowane $\mathrm{w}$ oparciu o osiągane wyniki edukacyjne. Literatura wskazuje wiele czynników wpływających na wyniki edukacyjne, t $\mathrm{j}$.:

indywidualne - cechy psychologiczne i charakterologiczne zdolności, ambicje; szkolne - sposoby i wysokość finansowania oświaty, warunki nauczania, organizacja i wyposażenie techniczne szkół, jakość i kwalifikacje kadry nauczycielskiej, programy nauczania;

środowiskowe rodzinne - status społeczno-majątkowy (dochód, wykształcenie pozycja zawodowa);

środowiskowe otoczenie lokalne - kondycja społeczno-gospodarcza, bezrobocie, specjalizacja funkcjonowania gminy itd.;

regionalne - tradycje kulturowo-cywilizacyjne, kapitał społeczny

(https://www.igipz.pan.p1/...).

Państwo czy samorząd, przejmując odpowiedzialność za organizację i finansowanie oświaty, koncentruje się przede wszystkim na funkcjonowaniu samej szkoły. 
Najogólniej można stwierdzić, że zakres finansowania oświaty na całym świecie jest dość ściśle związany $\mathrm{z}$ dochodem narodowym. W ostatnich latach w większości krajów wydatki na oświatę na poziomie edukacji podstawowej i średniej wyniosły przeciętnie 3-4\% PKB (przeciętnie w krajach OECD w 2013 roku przeznaczono na oświatę 3,7\% PKB) (OECD 2016). Jest to dość znaczący poziom, ponieważ jeszcze w XIX wieku wydatki na oświatę w relacji do PKB kształtowały się na poziomie znacznie poniżej $2 \%$, a według niektórych obliczeń nawet poniżej 1\%. Jak wskazują badania, największy wpływ na wyniki osiągane przez uczniów ma status społeczno-ekonomiczny ich rodziców, tzn. zawód wykonywany, z uwzględnieniem prestiżu, wykształcenie i zarobki (Jeżowski 2012). Co więcej, zaobserwowano, że dwa czynniki: pochodzenie społeczne ucznia i pochodzenie społeczne innych uczniów mają największy wpływ na wyniki testów kompetencyjnych - zarówno wynik ucznia, jak i zbiorczy wynik szkoły (Białecki, Haman 2003). Szkoła powinna więc budować środowisko sprzyjające niwelowaniu tych różnic.

Celem pracy jest przedstawienie finansowania edukacji w oparciu o dane liczbowe opisujące wydatki na oświatę $\mathrm{i}$ ich zmianę $\mathrm{w}$ wybranych krajach w kontekście poziomu umiejętności uczniów, którzy ukończyli 15. rok życia i brali udział w badaniu kompetencji w ramach międzynarodowego badania kordynowanego przez (OECD) - Program Międzynarodowej Oceny Umiejętności Uczniów (PISA ${ }^{1}$ ). Na etapie projektowania badania, którego celem jest sprawdzenie nierówności edukacyjnej, postawiono następujące hipotezy badawcze:

H1: W krajach Europy skala nierówności w umiejętnościach edukacyjnych uczniów, którzy ukończyli 15. rok życia, nie jest wysoka.

H2: Istnieje zwiazek pomiędzy poziomem finansowania oświaty a efektami edukacyjnymi uczniów.

Hipoteza H1 zakłada, że w Europie istnieją nierówności w umiejętnościach edukacyjnych uczniów, mierzone w badaniu Program Międzynarodowej Oceny Umiejętności Uczniów (PISA). W szacowaniu poziomu nierówności wykorzystano wskaźniki koncentracji HHI i nierówności Giniego. Oznacza to, że istnieją państwa o niewystarczającym poziomie umiejętności w trzech obszarach: czytaniu i interpretacji, matematyce oraz rozumowaniu w naukach przyrodniczych. Weryfikacja hipotezy H1 obejmuje nie tylko analizę policzonej koncentracji, na podstawie wybranych wskaźników, ale również wskazuje państwa charakteryzujące się najniższą i najwyższą nierównością edukacyjną. Konstrukcja hipotezy H2 zakłada, że istnieje statystycznie istotna zależność pomiędzy finansowaniem oświaty a efektami edukacyjnymi uczniów.

\section{Finansowanie oświaty na świecie}

W znacznej części krajów UE i OECD większość wydatków finansowana jest ze środków publicznych (przeciętnie 0,3\% PKB w 2013 roku stanowiły środki prywatne) (OECD 2016). W Unii Europejskiej powszechne jest finansowanie

\footnotetext{
${ }^{1}$ Programme for International Student Assessment.
} 
szkolnictwa przez sektor publiczny, wyjątek stanowią Holandia i Belgia. Wielkość środków publicznych przeznaczanych na finansowanie oświaty jest dość zróżnicowana. Przeciętnie jest to 3,4\% PKB, jednak część krajów, szczególnie zamożniejszych, wydaje więcej - np. 4,7\% PKB w Norwegii czy 4,5\% PKB w Danii. W tym samym okresie Polska przeznaczyła na edukację podstawową i średnią 3,1\% PKB, a więc poniżej średniej dla państw OECD (Rysunek 1).

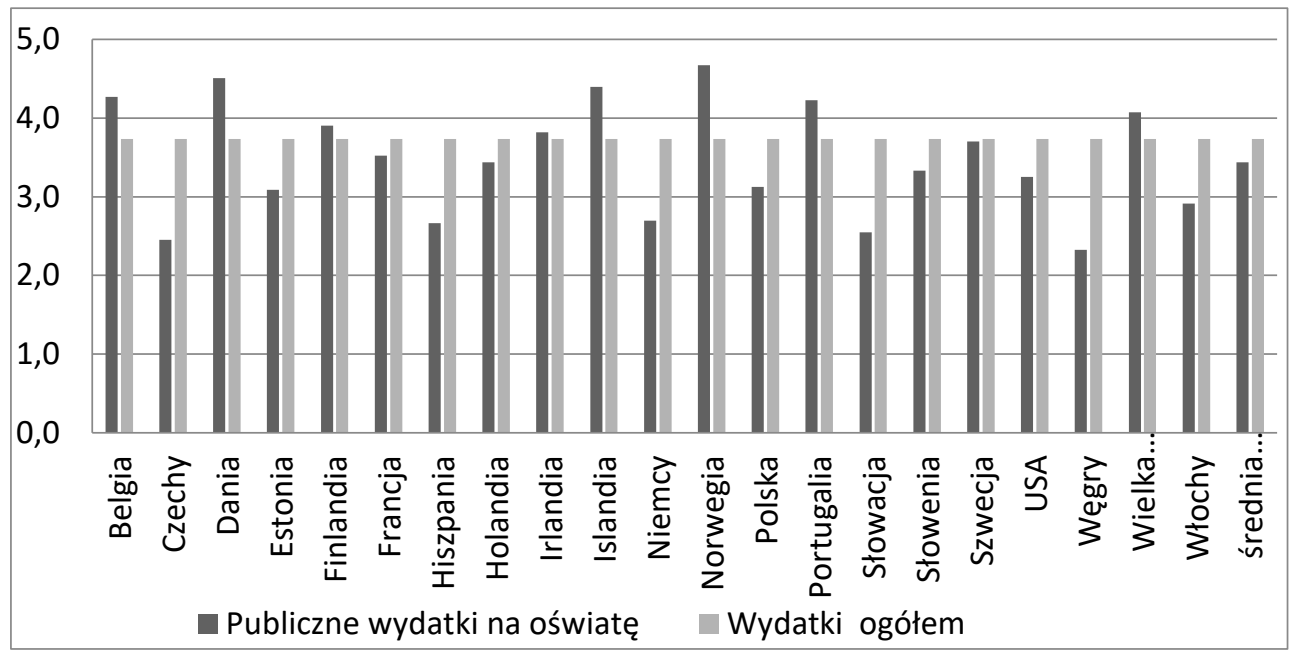

Rysunek 1. Wydatki ogółem i wydatki publiczne na oświatę podstawową i średnią w wybranych krajach OECD w 2013 r. (\% PKB)

Źródło: Opracowanie własne na podstawie (OECD 2016)

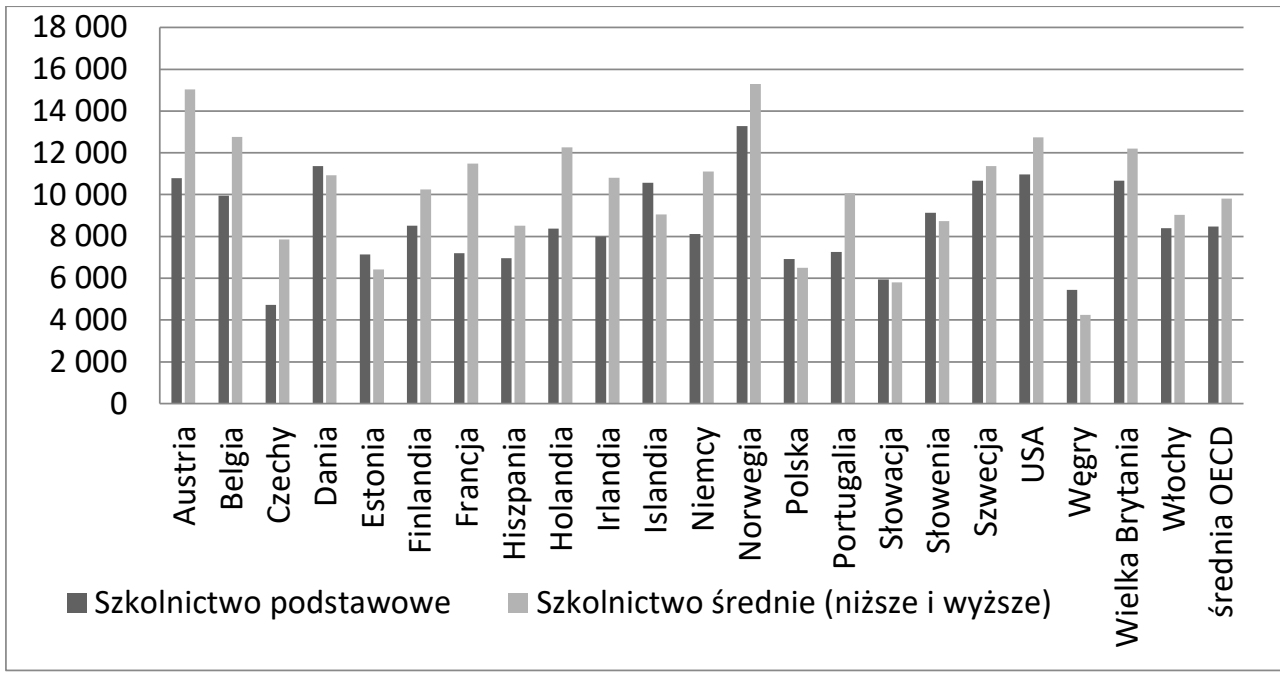

Rysunek 2. Roczne wydatki ogółem na jednego ucznia w 2013 r. w wybranych krajach OECD (PPP USD, ceny stale)

Źródło: Opracowanie własne na podstawie (OECD 2016) 
Istotniejsze różnice ujawnia analiza wydatków na jednego ucznia - w 2013 roku Polska wydała na edukację podstawową 6919 USD $^{2}$ (OECD 2016), a na edukację średnią (niższą i wyższą) - 6505 USD, co oznacza poziom znacząco niższy niż średnia dla krajów OECD, wynosząca odpowiednio 8477 USD i 9811 USD (Rysunek 2) (OECD 2016).

Optymizmem może napawać fakt, że dynamika tych wydatków nie tylko nadąża za średnim wzrostem w krajach OECD. W analizowanym okresie wydatki ogółem na oświatę wzrosły w Polsce o 7\% (przeciętnie w OECD - 6\%) (Rysunek 3), a wydatki na jednego ucznia (w Polsce, per capita) o $28 \%$ w stosunku do $8 \%$ przeciętnego wzrostu dla krajów OECD (Rysunek 4).

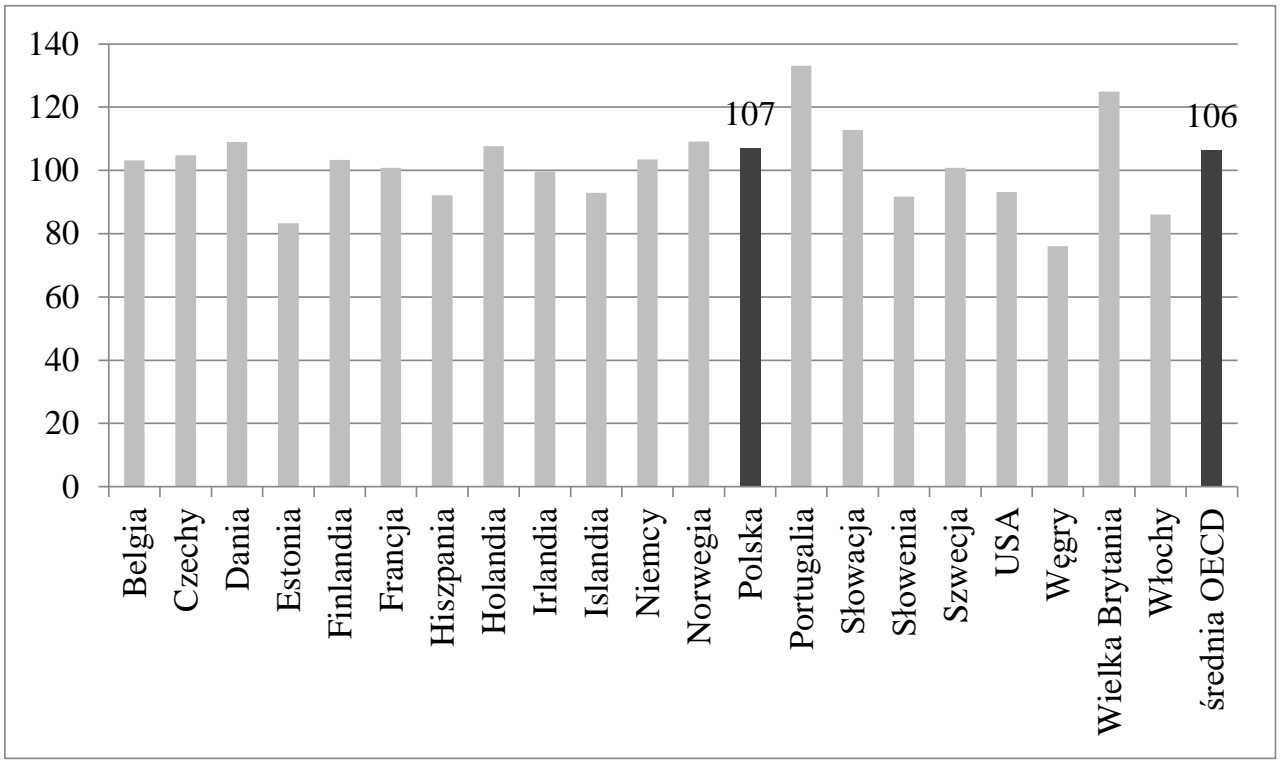

Rysunek 3. Zmiana wydatków ogółem na oświatę (PPP USD) w latach 2008-2013 (2008=100)

Źródło: Opracowanie własne na podstawie (OECD 2016)

${ }^{2}$ Wszystkie dane przeliczone według parytetu siły nabywczej. 


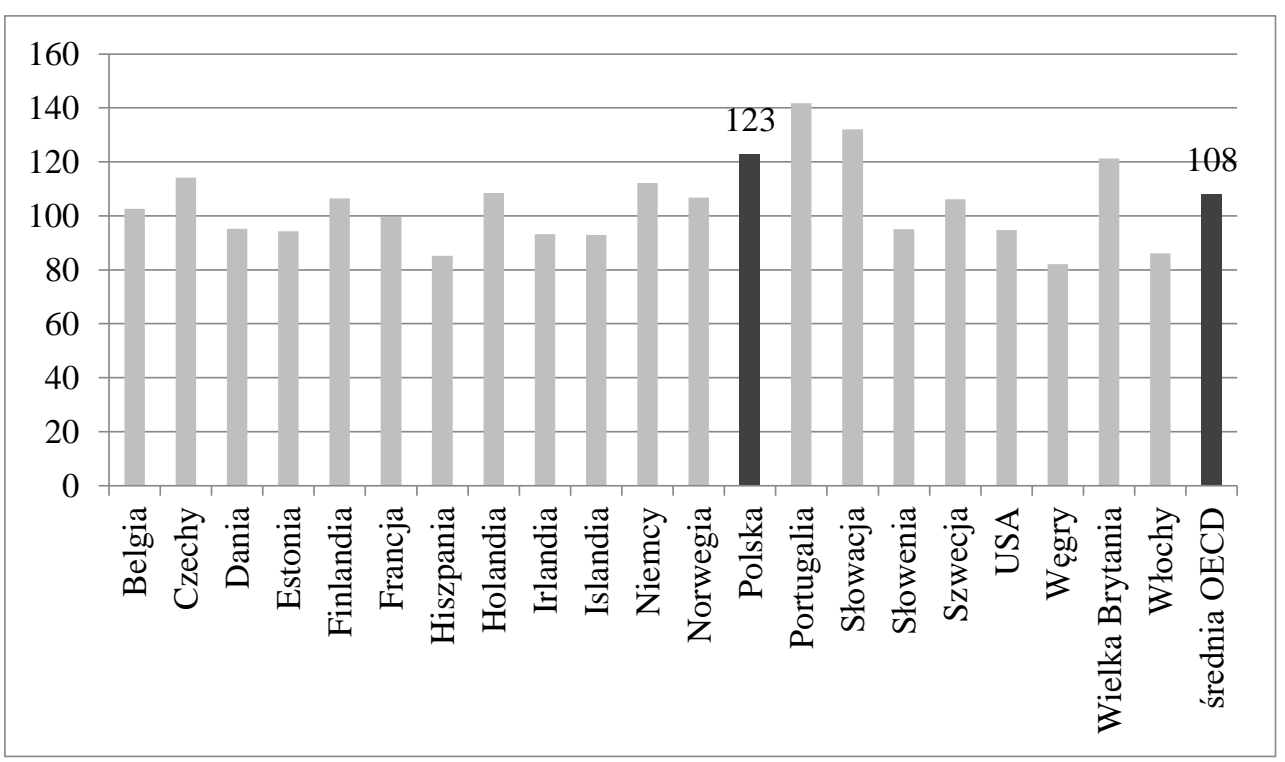

Rysunek 4. Zmiana wydatków na oświatę per capita (PPP USD) w latach 2008-2013 (2008=100)

Źródło: Opracowanie własne na podstawie (OECD 2016)

W analizie wydatków na oświatę ma znaczenie nie tylko ogólny poziom wydatków, ale również odsetek wydatków publicznych na oświatę obowiązkową, który dla krajów UE kształtuje się następująco:

wydatki publiczne na kształcenie obowiązkowe do wydatków ogółem: 43,4\% (w poszczególnych krajach od 33,8\% do $91,1 \%$ );

wydatki publiczne na kształcenie obowiązkowe do PKB: 2,3\% (odpowiednio od $2,1 \%$ do $3,9 \%)$.

\section{Pomiar efektów ksztalcenia uczniów}

Początkowo analizy efektów edukacyjnych prowadzone m.in. przez I. Białeckiego (Białecki, Haman 2003) z zespołem, J. Herczyńskiego i M. Herbsta (Herczyński, Herbst 2002) oraz P. Śleszyńskiego (Śleszyński 2004; Jeżowski 2012) koncentrowały się przede wszystkim na próbie dokonania syntezy wyników badań OECD oraz CKE i OKE. Od 2000 roku badane są umiejętności uczniów, którzy ukończyli 15. rok życia, w ramach międzynarodowego projektu koordyno-

- wanego przez Organizację Współpracy Gospodarczej i Rozwoju (OECD) -

- $\quad$ Programme for International Student Assessment (PISA). Badanie PISA sprowa-

- dza pomiar poziomu umiejętności edukacyjnych do trzech obszarów:

matematyki $\left(\mathrm{X}_{\mathrm{m}}\right)$,

czytania i interpretacji $\left(\mathrm{X}_{\mathrm{r}}\right)$,

rozumowania w naukach przyrodniczych $\left(\mathrm{X}_{\mathrm{s}}\right)$, 
w jakie szkoła, w danym systemie edukacyjnym, wyposaża uczniów na progu ich dorosłości, a które wpływają na dalszą ścieżkę kariery edukacyjnej i zawodowej.

Umiejętności uczniów w dziedzinie matematyki mierzone wartością wskaźnika $\left(\mathrm{X}_{\mathrm{m}}\right)$ w latach 2006-2015 ulegały zmianie, a w 2015 roku najwyższe wyniki uzyskali uczniowie w Szwajcarii, Estonii i Holandii.

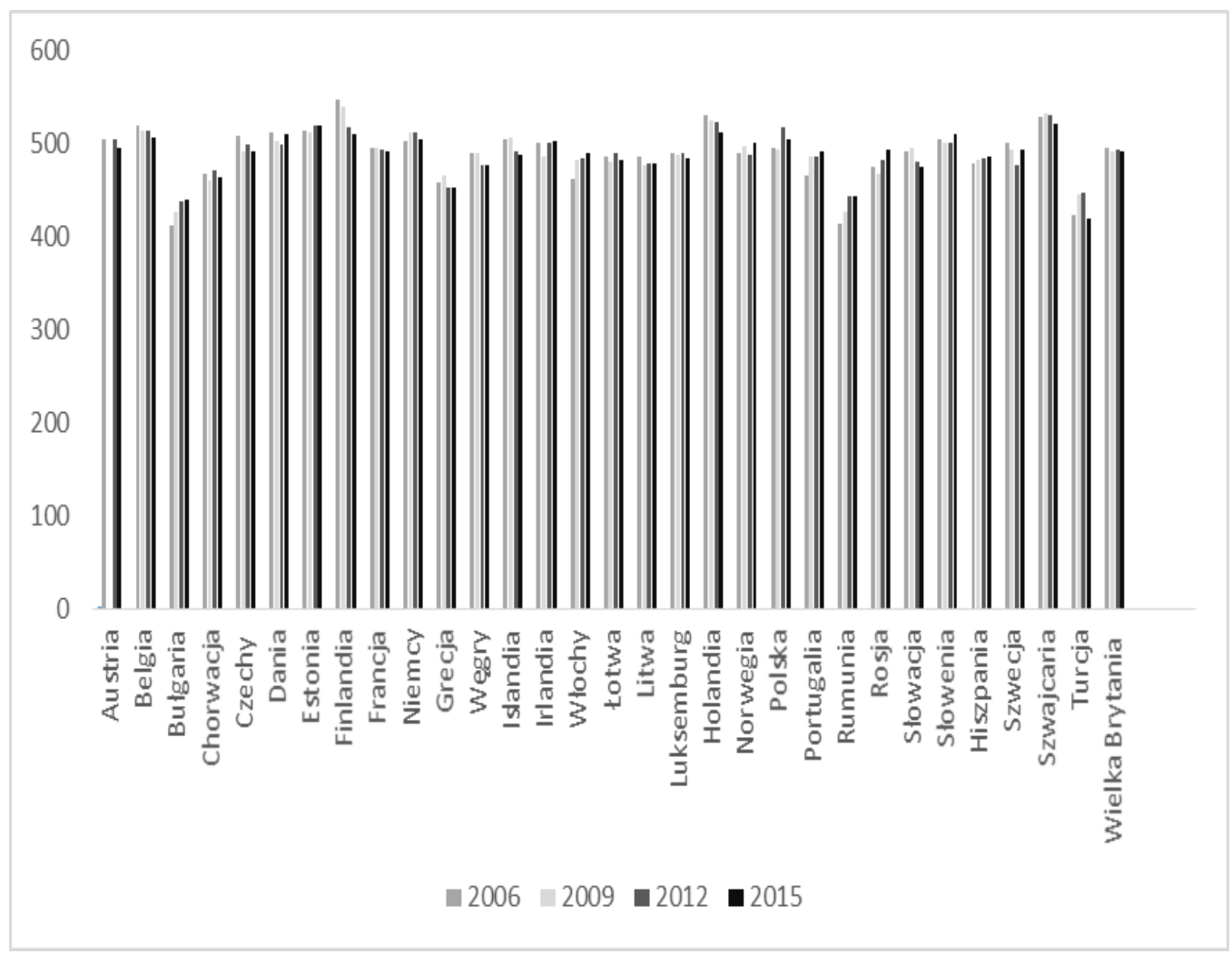

\section{Rysunek 5. Wartość wskaźnika efektów edukacyjnych dla krajów europejskich z matematyki w badaniach w 2006, 2009, 2012, 2015 roku}

Źródło: Opracowanie własne na podstawie danych Programu Międzynarodowej Oceny Umiejętności Uczniów (PISA 2006; 2009; 2012; 2015)

Analiza wyników z matematyki $\left(\mathrm{X}_{\mathrm{m}}\right)$ z 2006 i 2015 roku wskazuje, że w zdecydowanej większości krajów w roku 2015 nastąpił spadek wyniku o kilka, kilkanaście lub nawet kilkadziesiąt punktów. Tylko sześć krajów, tj. Portugalia, Włochy, Szwecja, Norwegia, Niemcy i Polska, zanotowało wzrost przeciętnych wyników. Natomiast polscy gimnazjaliści w zakresie umiejętności matematycznych osiągnęli wysoką pozycję $\mathrm{X}_{\mathrm{m} 2015}-504$ punkty. 
Tabela 1. Wartość wskaźnika efektów edukacyjnych (średniego wyniku uczniów) z matematyki w badaniach od 2006 do 2015 roku dla pięciu najlepszych i pięciu najgorszych krajów europejskich

\begin{tabular}{|l|c|c|c|l|c|c|r|}
\hline $\begin{array}{c}\text { Państwa } \\
\text { o najwyższy } \\
\text { m wskaźniku } \\
\text { w 2006 roku }\end{array}$ & $\mathbf{X}_{\mathbf{m 2 0 0 6}}$ & $\mathbf{X}_{\mathbf{m 2 0 1 5}}$ & $\begin{array}{c}\mathbf{X}_{\mathbf{m 2 0 0 6}} \\
-\mathbf{X}_{\mathbf{m 2 0 1 5}}\end{array}$ & $\begin{array}{c}\text { Państwa } \\
\text { o najniższym } \\
\text { wskaźniku } \\
\text { w 2006 roku }\end{array}$ & $\mathbf{X}_{\mathbf{m 2 0 0 6}}$ & $\mathbf{X}_{\mathbf{m 2 0 1 5}}$ & $\begin{array}{r}\mathbf{X}_{\mathbf{m 2 0 6}} \\
\mathbf{- X}_{\mathbf{m 2 0 1 5}}\end{array}$ \\
\hline Finlandia & 548 & 511 & -37 & Litwa & 486 & 478 & -8 \\
\hline Holandia & 531 & 512 & -19 & Lotwa & 486 & 482 & -4 \\
\hline Belgia & 520 & 507 & -13 & Hiszpania & 480 & 486 & 6 \\
\hline Dania & 513 & 511 & -2 & Portugalia & 466 & 492 & 26 \\
\hline Czechy & 510 & 492 & -18 & Włochy & 462 & 490 & 28 \\
\hline
\end{tabular}

Źródło: Opracowanie własne na podstawie danych Programu Międzynarodowej Oceny Umiejętności Uczniów (PISA 2006; 2015)

Co więcej, umiejętności uczniów, którzy ukończyli 15. rok mierzone wartością wskaźnika w czytaniu i interpretacji $\left(\mathrm{X}_{\mathrm{r}}\right)$ od 2006-2015 roku ulegały zmianie, a w 2015 roku najlepsze wyniki osiągnęła Finlandia, Irlandia, Estonia.

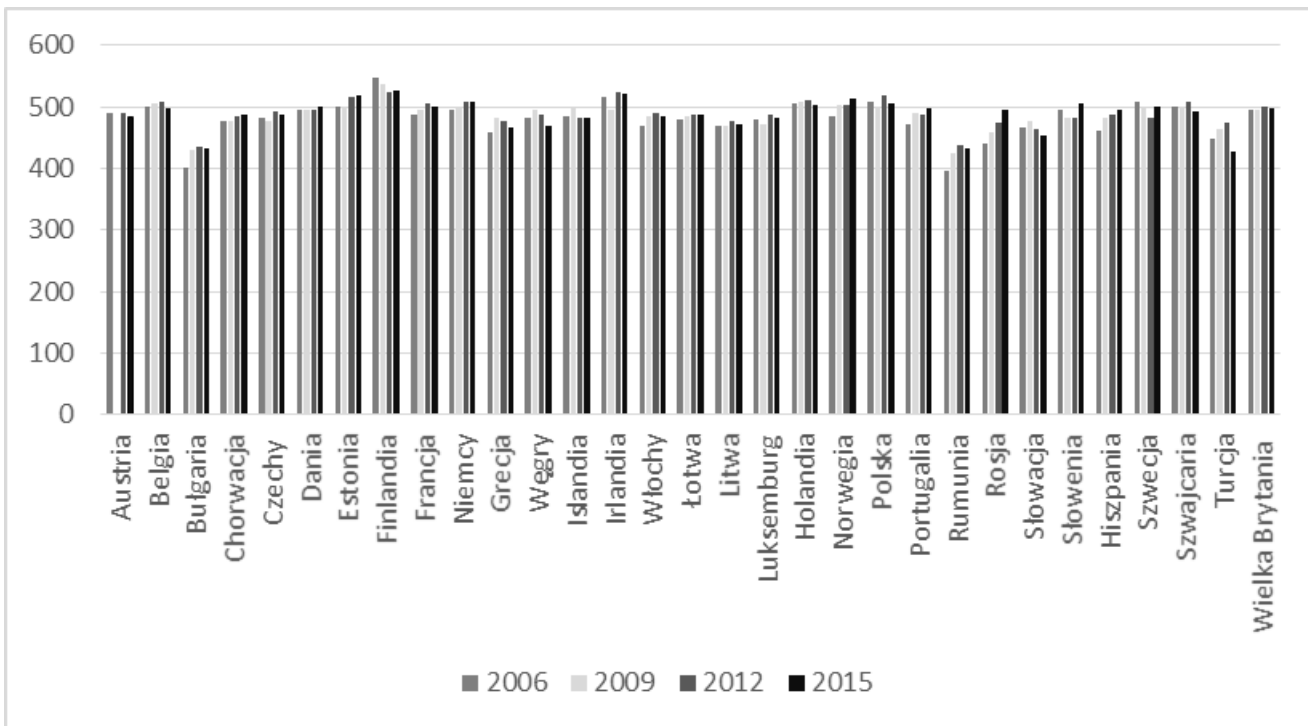

Rysunek 6. Wartość wskaźnika efektów edukacyjnych dla krajów europejskich z czytania i interpretacji w 2006, 2009, 2012, 2015 roku

Źródło: Opracowanie własne na podstawie danych Programu Międzynarodowej Oceny Umiejętności Uczniów (PISA 2006; 2009; 2012; 2015)

W zakresie umiejętności czytania i interpretacji (Tabela 2), w porównaniu $\mathrm{z}$ innymi krajami świata, Polska znalazła się na wysokim miejscu w rankingu; w Europie, jeśli uwzględnić błąd statystyczny, lepsze średnie wyniki osiągnęli 
tylko uczniowie z Finlandii, Irlandii i Niemiec. W 2015 roku Polska osiągnęła bardzo wysokie rezultaty (506 punktów), a w 2006-2015 widoczna jest jeszcze większa poprawa tych wyników.

Tabela 2. Wartość wskaźnika efektów edukacyjnych (średniego wyniku uczniów) z czytania i interpretacji w badaniach od 2006 do 2015 roku dla pięciu najlepszych i pięciu najgorszych krajów europejskich

\begin{tabular}{|l|c|c|c|c|c|r|r|}
\hline $\begin{array}{c}\text { Państwa } \\
\text { o najwyższy } \\
\text { m wskaźniku } \\
\text { w 2006 roku }\end{array}$ & $\mathbf{X}_{\mathbf{m} 2006}$ & $\mathbf{X}_{\mathbf{m} 2015}$ & $\begin{array}{c}\mathbf{X}_{\mathbf{m} 2006-} \\
-\mathbf{X}_{\mathbf{m} 2015}\end{array}$ & $\begin{array}{c}\text { Państwa } \\
\text { o najniższym } \\
\text { wskaźniku } \\
\text { w 2006 roku }\end{array}$ & $\mathbf{X}_{\mathbf{m} 2006}$ & $\mathbf{X}_{\mathbf{m 2 0 1 5}}$ & $\begin{array}{c}\mathbf{X}_{\mathbf{m} 2006-} \\
-\mathbf{X}_{\mathbf{m} 2015}\end{array}$ \\
\hline Finlandia & 547 & 526 & -21 & Portugalia & 472 & 498 & 26 \\
\hline Irlandia & 517 & 521 & 4 & Litwa & 470 & 472 & 2 \\
\hline Polska & $\mathbf{5 0 8}$ & $\mathbf{5 0 6}$ & -2 & Włochy & 469 & 485 & 16 \\
\hline Szwecja & 507 & 500 & -7 & Hiszpania & 461 & 496 & 35 \\
\hline Holandia & 507 & 503 & -4 & Grecja & 460 & 467 & 7 \\
\hline
\end{tabular}

Źródło: Opracowanie własne na podstawie danych Programu Międzynarodowej Oceny Umiejętności Uczniów (PISA 2006; 2015)

Również umiejętności uczniów, którzy ukończyli 15. rok życia liczone wartością wskaźnika od 2006 do 2015 roku ulegały zmianie, a w 2015 roku wartość ta była największa w Finlandii, Estonii i Holandii.

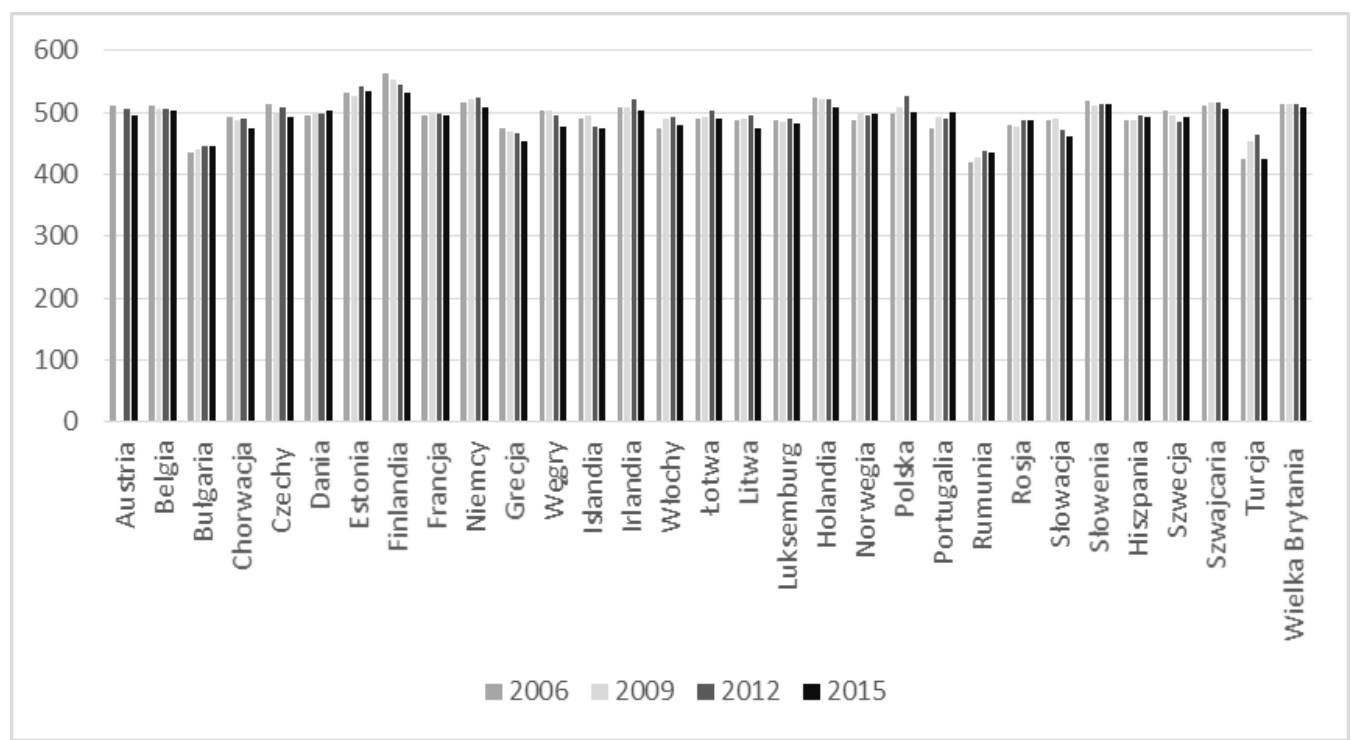

Rysunek 7. Wartość wskaźnika efektów edukacyjnych dla krajów europejskich z rozumowania $w$ naukach przyrodniczych $w$ 2006, 2009, 2012, 2015 roku

Źródło: Opracowanie własne na podstawie danych Programu Międzynarodowej Oceny Umiejętności Uczniów (PISA 2006; 2009; 2012; 2015) 
Tabela 3. Wartość wskaźnika efektów edukacyjnych (średniego wyniku uczniów) dla krajów europejskich z rozumowania w naukach przyrodniczych w badaniach od 2006 do 2015 roku dla pięciu najlepszych i pięciu najgorszych krajów europejskich

\begin{tabular}{|l|c|c|r|l|c|r|r|}
\hline $\begin{array}{c}\text { Państwa } \\
\text { o najwyższy } \\
\text { m wskaźniku } \\
\text { w 2006 roku }\end{array}$ & $\mathbf{X}_{\mathbf{m 2 0 0 6}}$ & $\mathbf{X}_{\mathbf{m} 2015}$ & $\begin{array}{c}\mathbf{X}_{\mathbf{m} 2006-} \\
-\mathbf{X}_{\mathbf{m 2 0 1 5}}\end{array}$ & $\begin{array}{c}\text { Państwa } \\
\text { o najniższym } \\
\text { wskaźniku } \\
\text { w 2006 roku }\end{array}$ & $\mathbf{X}_{\mathbf{m 2 0 0 6}}$ & $\mathbf{X}_{\mathbf{m 2 0 1 5}}$ & $\begin{array}{r}\mathbf{X}_{\mathbf{m} 2006} \\
\mathbf{- X}_{\mathbf{m 2 0 1 5}}\end{array}$ \\
\hline Finlandia & 563 & 531 & -32 & Włochy & 475 & 481 & +6 \\
\hline Estonia & 531 & 534 & 3 & Portugalia & 474 & 501 & +27 \\
\hline Holandia & 525 & 509 & -16 & Grecja & 473 & 455 & -18 \\
\hline Słowenia & 519 & 513 & -6 & Bułgaria & 434 & 446 & +12 \\
\hline Niemcy & 516 & 509 & -7 & Rumunia & 418 & 435 & +17 \\
\hline
\end{tabular}

Źródło: Opracowanie własne na podstawie danych Programu Międzynarodowej Oceny Umiejętności Uczniów (PISA 2006; 2015)

Jeśli chodzi o wyniki testu z zakresu rozumowania w naukach przyrodniczych, można zauważyć, że różnica między latami 2006 i 2015 była istotna statystycznie zaledwie w kilku krajach. Polscy uczniowie poprawili w analizowanym okresie wyniki o 3 pkt. Z tej części jednak uczniowie uzyskali najniższe wyniki (Tabela 3).

\section{Metodologia i dane}

Do badania nierówności efektów edukacji zastosowano:

wskaźnik Herfindahla-Hirschmana (HHI);

indeks Giniego.

HHI to wskaźnik koncentracji zmiennych, $\mathrm{tj}$.:

efektów edukacyjnych w matematyce $\left(\mathrm{X}_{\mathrm{m}}\right)$,

efektów edukacyjnych z czytania i interpretacji $\left(\mathrm{X}_{\mathrm{r}}\right)$,

efektów edukacyjnych $\mathrm{w}$ rozumowaniu zjawisk w naukach przyrodniczych $\left(\mathrm{X}_{\mathrm{s}}\right)$.

$$
H H I=\sum_{i=1}^{n}\left(\frac{i}{n}\right)^{2}=\sum_{i=1}^{n} R_{i}^{2}
$$

gdzie:

$R_{i}$ - oznacza udziały efektu edukacyjnego z danego obszaru dla kraju w całkowitym poziomie efektów edukacyjnych w danym obszarze dla wszystkich badanych krajów (https://www.justice.gov/...).

Wartość wskaźnika HHI mniejsza od 0,15 oznacza brak koncentracji danej cechy, gdy HHI przyjmuje wartość od 0,15 do 0,25 , to analizowana cecha jest umiarkowanie skoncentrowana, natomiast wartości HHI większe lub równe 0,25 oznaczają silną koncentrację (https://www.justice.gov/...).

Indeks Giniego jest stosowaną W statystyce miarą koncentracji (nierównomierności) rozkładu zmiennej losowej. W celu określenia współczynnika $\operatorname{GIH}(x)$ skorzystano ze wzoru: 


$$
G I H(x)=\frac{\sum_{i=1}^{n}(2 i-n-1) x_{i}}{n^{2} \bar{x}}
$$

gdzie:

$x_{i}$ - jednostkowa $i$-ta wartość badanego zjawiska,

$\bar{x}$ - średnia arytmetyczna,

$i$ - pozycja szeregu,

$n$ - liczebność próby.

Współczynnik Giniego przyjmuje wartości z przedziału [0;1], często jednak wyraża się go w procentach. Dogodny zakres wskaźnika Giniego, od 0 do 1, stanowi miarę względną pozwalającą na łatwe porównanie stopnia nierówności w populacjach o różnej liczebności i różnych średnich edukacyjnych (Kennedy i in. 1998; Navarro $i$ in. 2006). Technicznie, dzieląc przedział [0;1] na trzy części: $\langle 0-0,3(3)\rangle,\langle 0,3(3)-0,6(6)\rangle$ oraz $\langle 0,6(6)-1>$, możemy nadać wartościom wspó1czynnika Giniego odpowiednio znaczenia: niski, umiarkowany i wysoki poziom (Kurowska 2011; Szajt 2014).

W celu zweryfikowania hipotezy $\mathrm{H} 2$ oszacowano, metodą najmniejszych kwadratów, model ekonometryczny, w którym zmienną objaśnianą był wynik testu PISA, a zmienną objaśniającą - poziom wydatków na oświatę.

W badaniu wykorzystano dane pochodzące z projektu koordynowanego przez OECD Programme for International Student Assessment (PISA) oraz dane OECD dotyczące wydatków na oświatę.

\section{Wyniki i dyskusja}

Na podstawie wytypowanych zmiennych opisujących nierówność edukacyjną ustalono wartości wskaźnika HHI (Tabela 4).

Tabela 4. Wskaźnik Herfindahla-Hirschmana i współczynnik Giniego w latach 2006-2015

\begin{tabular}{cccccccccc}
\hline \multicolumn{1}{c}{ HHI } & \multicolumn{7}{c}{ GIN } \\
\hline & $\mathbf{2 0 0 6}$ & $\mathbf{2 0 0 9}$ & $\mathbf{2 0 1 2}$ & $\mathbf{2 0 1 5}$ & & $\mathbf{2 0 0 6}$ & $\mathbf{2 0 0 9}$ & $\mathbf{2 0 1 2}$ & $\mathbf{2 0 1 5}$ \\
\hline $\mathbf{X}_{\mathbf{m}}$ & 0,033 & 0,033 & 0,033 & 0,033 & $\mathbf{X}_{\mathbf{m}}$ & 0,034 & 0,029 & 0,026 & 0,026 \\
\hline $\mathbf{X}_{\mathbf{r}}$ & 0,033 & 0,033 & 0,033 & 0,033 & $\mathbf{X}_{\mathbf{r}}$ & 0,033 & 0,023 & 0,023 & 0,027 \\
\hline $\mathbf{X}_{\mathbf{s}}$ & 0,033 & 0,033 & 0,033 & 0,033 & $\mathbf{X}_{\mathbf{s}}$ & 0,031 & 0.026 & 0.027 & 0,028 \\
\hline
\end{tabular}

Źródło: Obliczenia własne

W konstrukcji hipotezy H1 zakładaliśmy, że w Europie istnieje relatywnie niska lub umiarkowana nierówność w umiejętnościach edukacyjnej uczniów. W tym celu przeanalizowano wartości otrzymanych współczynników HHI oraz GIN dla trzech zmiennych. $\mathrm{Z}$ obliczeń wynika, że w badanym okresie wartość współczynnika koncentracji (HHI) nie zmieniła się, a nierówność (GIN) zmalała. Podsumowując, można zauważyć, że otrzymane niskie wartości koncentracji (HHI) i umiarkowany 
poziom nierówności (GIN) w badanym okresie lat 2006-2015 pozwalają na przyjęcie hipotezy H1.

Aby udowodnić hipotezę $\mathrm{H} 2$, do analizy wykorzystano narzędzia modelowania ekonometrycznego, obliczając regresję liniową, metodą najmniejszych kwadratów dla danych panelowych zbilansowanych, 27 państw w czterech okresach (2006, 2009, 2012, 2015) i 108 obserwacji. Zbudowano trzy modele ekonometryczne, gdzie zmiennymi objaśnianymi były umiejętności edukacyjne z matematyki $\left(X_{m}\right)$, czytania i interpretacji $\left(\mathrm{X}_{\mathrm{r}}\right)$ oraz rozumowania w naukach przyrodniczych $\left(\mathrm{X}_{\mathrm{s}}\right)$, a jedną zmienną objaśniającą były wydatki publiczne na oświatę podstawową i średnią jako procent PKB w krajach UE. Oszacowano trzy funkcje regresji dla zmiennych, $\mathrm{tj}$.:

umiejętności edukacyjne z matematyki $\left(\mathrm{X}_{\mathrm{m}}\right)$ :

$$
\begin{aligned}
\text { MATit }= & 447,898+8,308 \mathrm{WYDit} \\
& (80,840),(8,113)^{3}
\end{aligned}
$$

umiejętności edukacyjne z czytania i interpretacji $\left(\mathrm{X}_{\mathrm{r}}\right)$ :

$$
\begin{aligned}
\text { CZYTit }= & 442,444+8,950 \mathrm{WYDit} \\
& (73,522),(8,097)
\end{aligned}
$$

umiejętności edukacyjne z rozumienia przyrody:

$$
\begin{gathered}
\text { PRZYRit }=460,83+6,804 \text { WYDit } \\
(82,468),(6,392)
\end{gathered}
$$

Współczynniki dla równań wynoszące 447,898; 442,444; 460,83 wskazują na dodatni wpływ wydatków publicznych na oświatę podstawową na poziom średniej badanych umiejętności uczniów.

$\mathrm{Z}$ równań (3), (4) i (5) wynika, że w badanym okresie (2006-2015), licząc w wielkościach realnych, przeciętne zwiększenie wydatków o $1 \%$ PKB zwiększa średnio umiejętności edukacyjne z matematyki o 8,3 punktu, z czytania o 8,9 punktu i z rozumowania w naukach przyrodniczych o 6,8 punktu.

Model (3) charakteryzuje się odpowiednim dopasowaniem do danych empirycznych $\left(\mathrm{R}^{2}=0,3806 ; \mathrm{F}_{(1,106)}=65,8171 ; \mathrm{p}<0,0001\right)$, podobnie jak model (4) $\left(\mathrm{R}^{2}=0,3821 ; \mathrm{F}_{(1,106)}=65,5629 ; \mathrm{p}<0,0001\right)$. W modelu (5) dopasowanie do danych empirycznych jest nieznacznie niższe $\left(R^{2}=0,2782 ; F_{(1,106)}=40,8607\right.$; $\mathrm{p}<0,0001)$.

Co więcej, nie wszystkie zmienne objaśniane jednakowo w badanym okresie uległy wpływom zmiennej objaśniającej. W związku z tym przeprowadzono ocenę relatywnego znaczenia zmiennych $\mathrm{w}$ modelu ekonometrycznym dla wyjaśniania kształtowania się zmiennych objaśnianych.

\footnotetext{
${ }^{3} \mathrm{~W}$ nawiasach podano $t$-Studenta.
} 
Miarą służącą do oceny relatywnego znaczenia zmiennej objaśniającej w WYDit w wyjaśnianiu zmian zmiennych objaśnianych MATit, CZYTit, PRZYRit jest zmodyfikowany współczynnik ważności zdefiniowany następująco (Nowak 1994, s. 62; Stec 2011):

$$
\mathrm{W}=a i / x i
$$

gdzie:

$x i$ - średnia arytmetyczna zmiennej objaśnianej,

$a i$ - wartość oceny parametru strukturalnego.

Obliczone wartości współczynnika ważności ${ }^{4} \mathrm{~W}_{\mathrm{MAT}}=1,682, \mathrm{~W}_{\mathrm{CZYT}}=1,830$, $\mathrm{W}_{\mathrm{PRZYR}}=1,366$ pozwalają zauważyć, że relatywnie wydatki publiczne na oświatę podstawową i średnią jako procent PKB silniej wpływają na poziom umiejętności kolejności cechy: CZYTit, MATit, PRZYRit. Podsumowując, można przyjąć, że wzrost wydatków publicznych na oświatę podstawową i średnią jako procent PKB wywoła zmianę i większy efekt o $47 \%$ dla wyników testów umiejętności czytania $\mathrm{w}$ porównaniu $\mathrm{z}$ rozumieniem przyrody.

Wyniki te pozwalają na przyjęcie hipotezy $\mathrm{H} 2$ mówiącej, że istnieje związek pomiędzy finansowaniem oświaty na świecie a efektami edukacyjnymi uczniów.

\section{Podsumowanie}

Oświata jest jednym z podstawowych dóbr społecznych dostarczanych przez państwa rozwinięte, wywiera bowiem ogromny wpływ na funkcjonowanie i rozwój nowoczesnych społeczeństw, umożliwiając pełne wykorzystanie potencjału drzemiącego w kapitale ludzkim. Poziom wydatków na edukację jest istotnym elementem w pomiarze jakości życia, m.in. w ramach wskaźnika HDI dwa parametry odwołują się wprost do oświaty - umiejętność czytania i pisania oraz wskaźnik skolaryzacji.

Przeprowadzone badania wskazują na niewielkie zróżnicowanie wyników nauczania 15-latków w krajach europejskich. Wyniki te mogą się wydawać zaskakujące, ponieważ poziom wydatków na oświatę jest w tych krajach dość różny, co może wskazywać, że duży potencjał do zmian leży w sferze organizacji nauczania (w tym w tworzeniu programów nauczania). Według M. Spitzera „wynik badania PISA jest nie tyle odbiciem sytuacji panującej w szkole, ile odzwierciedleniem stanu społeczeństwa" (Spitzer 2008). Nie oznacza to jednak, że wyniki nie mogą być wykorzystywane do promowania dobrych praktyk w edu-kacji. Sprawny system oświaty powinien nie tylko zapewniać równy dostęp do edukacji wszystkim dzieciom objętym obowiązkiem szkolnym, ale również prowadzić do możliwie największego zredukowania nierówności społecznych, umożliwiając wszystkim dzieciom równy start $\mathrm{w}$ dorosłe życie, co ma szczególne znaczenie w przypadku dzieci zagrożonych deprywacją społeczną. Aby cele te mogły być realizowane, konieczne są znaczne nakłady finansowe.

\footnotetext{
${ }^{4}$ Średnia podana w tysiącach punktów.
} 


\title{
Literatura
}

1. Białecki I., Haman J. (2003), Program Międzynarodowej Oceny Umiejętności Uczniów OECD/PISA. Wyniki polskie - raport z badań, Centrum Badań Polityki Naukowej i Szkolnictwa Wyższego UW, IFiS PAN, Warszawa.

2. Herczyński J., Herbst M. (2002), Pierwsza odsłona. Społeczne i terytorialne zróżnicowanie wyników sprawdzianu szóstoklasistów i egzaminu gimnazjalnego przeprowadzonych wiosna 2002 roku. Raport przygotowany na zlecenie Fundacji Klub Obywatelski, Fundacja Klub Obywatelski, Warszawa.

3. https://www.igipz.pan.p1/tl_files/igipz/.../012_Sleszynski_MENIS_2004_12_03.pdf (dostęp: 05.08.2017).

4. https://www.justice.gov/atr/horizontal-merger-guideline (dostęp: 05.08.2017).

5. Jeżowski A. (2012), Ekonomika oświaty w zarządzaniu szkoła, Wolters Kluwer, Warszawa.

6. Kennedy B.P., Kawachi I., Glass R., Prothrow-Stith D. (1998), Income Distribution, Socioeconomic Status, and Self Rated Health in the United States: Multilevel Analysis, „BMJ”, Vol. 317(7163), s. 917-921. DOI: 10.1136/bmj.317.7163.917

7. Kurowska A. (2011), Dynamika nierówności dochodowych w Polsce na tle innych krajów najważniejsze wnioski z badań i statystyk, Instytut Polityki Społecznej, Wydział Dziennikarstwa i Nauk Politycznych, Uniwersytet Warszawski, Warszawa, http://ips.uw.edu.pl/ pliki/analizyps/analizy_IPS-2_2011_pl.pdf (dostęp: 01.08.2017).

8. Navarro V., Muntaner C., Borrell C., Benach J., Quiroga Á., Rodríguez-Sanz M., Vergés N., Pasarín M.I. (2006), Politics and Health Outcomes, „The Lancet”, Vol. 368(9540), s. 1033-1037. DOI: 10.1016/S0140-6736(06)69341-0

9. Nowak E. (1994), Zarys metod ekonometrii. Zbiór zadań, Wydawnictwo Naukowe PWN, Warszawa.

10. OECD (2016), Education at a Glance 2016: OECD Indicators, OECD Publishing, Paris. DOI: $10.187 /$ eag-2016-en

11. PISA (2006-2015), Program Międzynarodowej Oceny Umiejętności Uczniów (PISA), http://www.ibe.edu.pl/pl/projekty-miedzynarodowe/pisa (dostęp: 01.08.2017).

12. Spitzer M. (2008), Jak się uczy mózg?, Wydawnictwo Naukowe PWN, Warszawa.

13. Stec M. (2011), Uwarunkowania rozwojowe województw w Polsce - analiza statystyczno-ekonometryczna, „Nierówności Społeczne a Wzrost Gospodarczy”, nr 20, s. 235-238.

14. Szajt M. (2014), Przestrzeń w badaniach ekonomicznych, Sekcja Wydawnictw Wydziału Zarządzania Politechniki Częstochowskiej, Częstochowa.

15. Śleszyński P. (2004), Ekonomiczne uwarunkowania wyników sprawdzianu szóstoklasistów i egzaminu gimnazjalnego przeprowadzonych w latach 2002-2004, „Egzamin. Biuletyn Badawczy Centralnej Komisji Egzaminacyjnej”, nr 2, s. 13-23.

\section{EXPENDITURE ON EDUCATION AND ATTAINED EDUCATIONAL EFFECTS}

\begin{abstract}
In most developed countries education is financed in the mixed-model, both form public and private funds, while a level of participation of private funds increases with transition to higher levels of education. The aim of this research is to analyse the level of inequality in education, based on the data describing spending on education in selected countries and the level of skills of students who have completed 15 year of life. The analysis employ the results of an international survey coordinated by the Organisation for Economic Cooperation and Development (OECD) - Programme for International Student Assessment (PISA).
\end{abstract}

Keywords: education, funding, inequality, PISA 